\title{
ANALISA COLLABORATIVE GOVERNANCE DALAM MENARIK INVESTASI ASING KAWASAN FREE TRADE ZONE BINTAN
}

\author{
Ady Muzwardi \\ International Relations Department, Universitas Maritim Raja Ali Haji \\ ady_muzwardi@umrah.ac.id
}

\begin{abstract}
ABSTRAK
Nilai Investasi yang besar merupakan salah satu sumber pemasukan negara. Sampai sekarang pengelolaan investasi di Indonesia belum dapat dikelola secara optimal, disebabkan salah satunya oleh sistem pengorganisasian pengelolaan investasi yang masih lemah. Studi ini bertujuan untuk menganalisis hubungan antar organisasi (collaborative governance) di dalam sistem pengorganisasian dalam pengembangan investasi di Kawasan Free Trade Zone Bintan. Metode penelitian yang digunakan adalah analisis jejaring koordinasi dengan kajian terhadap 3 aspek yaitu struktur pemerintahan, karaketristik pelayanan, interaksi operasional pada level kabupaten/ kota. Hasil analisis menemukan bahwa koordinasi antar organisasi tingkat provinsi dan kabupaten/kota masih cukup optimal. koordinasi secara horizontal maupun secara vertikal cukup terjalin secara optimal.
\end{abstract}

Kata Kunci: Investasi, collaborative governance,koordinasi

\section{ABSTRACT}

Large amount of investment is one of income sources for a country. Recently, the investment in Indonesia has not been managed optimally due to, one among others, poor organization system of investment management. This study is aimed at analyzing the collaborative governance within organization system in investment development at Free Trade Zone and Free Port Bintan. The research methodology used was Coordination Network Analysis with 3 aspects of study; those are governance structure, service characteristics, operational interaction on the level of regency The result of the analysis indicates that coordination between provincial and regency/city organizations is sufficiently optimally conducted. Horizontal and vertical coordination are sufficiently optimally established.

Keywords: Investment, Collaborative governance, coordination

\section{PENDAHULUAN}

Perkembangan paradigma baru pemerintah daerah yang menitikberatkan pada pelayanan masyarakat termasuk dalam mengidentifikasi kebutuhan investor sebagai langkah dalam meningkatkan pertumbuhan investasi di era kompetisi global dan untuk meningkatkan pertumbuhan ekonomi nasional. pemerintah sebagai lembaga Negara bukan hanya berfungsi sebagai pengatur tetapi juga sebagai penyedia layanan. Denhardt \& Denhardt (2003) menyatakan: 
“Government shouldn't be run like a business; it should be run like a democracy. Across this country and around the world, both elected and appointed public servants are acting on this principle and expressing renewed commitment to such ideal as the public interest, the governance process and expanding democratic citizenship. Administrators are realizing that the have much gain by "listening" to the public rather than "telling" and by "serving" rather than "steering"

Melihat persaingan dalam perebutan Foreign Direct Investment (FDI), pemerintah menyesuaikan fungsinya dengan perubahan lingkungan di dunia internasional dengan mengutamakan pelayanan publik. Paradigma pemerintah yang berorientasi pada pengembangan investasi di Indonesia mengacu pada Undang-Undang Nomor 40 tahun 2007 Tentang Penanaman Modal. Pelayanan bidang investasi merupakan pelayanan strategis yang dilakukan pemerintah. Kedudukan pelayanan bidang investasi khususnya perizinan dan non perizinan sangat strategis karena merupakan kunci pengembangan pertumbuhan ekonomi. Apabila pemerintah tidak menjalankan fungsi pelayanan investasi secara maksimal maka dapat berdampak pada kegagalan pengembangan investasi secara keseluruhan.

Secara politis rencana pemerintah dalam pengembangan investasi tertuang dalam dari pasal 33 ayat 4 yang menyatakan perekonomian nasional diselenggarakan berdasar atas demokrasi ekonomi dengan prinsip kebersamaan, efesiensi berkeadilan, berkelanjutan, berwawasan lingkungan, kemandirian, serta dengan menjaga keseimbangan dan kesatuan. Berdasarkan UUD 1945 tersebut pemerintah mempercepat pembangunan ekonomi nasional dengan peningkatan penanaman modal yang diantara lain dengan adanya peningkatan penanaman modal di wilayah tertentu untuk menarik potensi pasar internasional dan sebagai daya dorong guna meningkatkan daya tarik pertumbuhan suatu kawasan atau wilayah ekonomi khusus yang bersifat strategis bagi pengembangan perekonomian nasional salah satu instrument peningkatan penanaman modal adalah kebijakan Free Trade Zone (FTZ), FTZ adalah pelayanan investasi untuk menarik investor sebanyak-banyaknya melalui insentif free tax untuk impor. Namun faktual realita menunjukan pengelolaan pengembangan investasi di Indonesia belum optimal. Dikarenakan lemahnya collaborative governance.

Terdapat Salah satu teori yang bisa digunakan untuk melihat bagaimanakah sebetulnya hubungan antara pemerintah dengan masyarakat dalam pengelolaan kawasan free trade zone adalah teori collaborative governance atau kerjasama dalam menjalankan tata kelola pemerintahan. Emerson (2011) mendefinisikannya sebagai proses dan stuktur dari pengambilan kebijakan publik dan tata kelola pemerintahan dengan melibatkan masyarakat, swasta, dan NGOs dari berbagai institusi dan level yang ada untuk menentukan tujuan 
bersama yang sulit untuk bisa dirumuskan sendiri. Sementara Mc Guire (2006) menjelaskan bahwa collaborative governance adalah konsep di dalam manajemen pemerintahan sebagai proses fasilitasi dan pelaksanaan oleh berbagai institusi baik pemerintah, masyarakat, maupun NGOs yang bertujuan untuk menyelesaikan masalah bersama yang tidak bisa diselesaikan oleh satu institusi pemerintah saja.

Paradigma lain tentang collaborative governance dikemukakan oleh John Wanna (2008), yang mendefinisikan bahwa kerjasama memiliki makna bekerja sama dengan pihak lain, baik sifatnya individu, kelompok, maupun organisasi. Dengan merujuk pada Wildavsky (1973) dan Wanna (2008) mengemukakan bahwa kerjasama mencakup beberapa dimensi: Pertama, mencakup collaborative governance untuk membangun kebersamaan, meningkatkan konsistensi, dan meluruskan aktivitas antar aktor. Kedua, collaborative governance bisa juga merupakan sebagai proses negosiasi, yang mencakup suatu persiapan untuk berkompromi dan membuat kesepakatan. Ketiga, bisa juga merupakan bentuk antisipasi bersama melalui serangkaian aturan terhadap kemungkinan kekeliruan yang akan terjadi. Keempat, collaborative governance juga bisa merupakan kekuasaan dan paksaan, kemampuan untuk mendorong hasil. Kelima, collaborative governance mencakup komitmen masa depan dan intensitasnya, perencanaan atau persiapan untuk meluruskan aktivitas-aktivitas yang akan dilakukan. Dan yang terakhir, kerjasama mencakup keterlibatan, proses pengembangan motivasi internal dan komitmen personal terhadap proyek yang akan dikerjakan.

Perspektif lainnya dikemukakan oleh Chris Ansell dan Alison Gash (2008) yang mengemukakan bahwa yang dimaksud dengan collaborative governance adalah sebuah tata kelola pemerintahan dimana institusi-institusi pemerintahan secara langsung melibatkan aktor di luar pemerintah (baik masyakat/komunitas, NGOs, dan private sector) di dalam proses pengambilan keputusan secara formal, yang berorientasi pada kepentingan bersama. Tujuannya adalah untuk melaksanakan kebijakan dan mengelola program dan sumber daya secara bersama. Dari perspektif ini menurut Ansell dan Gash (2008) ada beberapa kata kunci penting yang harus dicatat yaitu: (1) kerjasama diinisiasi oleh institusi pemerintahan, (2) adanya keterlibatan aktor non-pemerintah, (3) seluruh aktor terlibat dalam proses pengambilan kebijakan, (4) forum kerjasama diorganisir dan dirancang secara bersama, (5) tujuan dari forum kerjasama adalah untuk membuat keputusan bersama-sama, dan (6) fokus dari kerjasama adalah dalam pengemabilan kebijakan dan tatakelola pemerintahan.

Dengan menggunakan istilah yang berbeda yaitu cross-sector collaboration, John M Bryson dan Barbara C. Crosby $(2006 ; 2012)$ mendefinisikan kerjasama sebagai proses 
sharing informasi, resources, aktivitas dan kapabilitas yang dilakukan oleh berbagai organisasi di dalam satu atau beberapa sektor untuk mendapatkan hasil yang diinginkan yang tidak bisa didapatkan apabila hanya dilakukan oleh organisasi-organisasi yang berada pada satu sektor saja. Bryson dan Corby menegaskan bahwa penggunaan istilah cross-sector collaboration untuk menunjukan adanya keterlibatan pihak pemerintah, business, nonprofit, lembaga charity, komunitas, dan institusi-institusi publik lainnya secara keseluruhan.

Model lainnya dikembangkan oleh Ansell dan Gash (2008) yang tediri dari dua tahapan yaitu starting condition, facilitative leadership, institutional design, collaborative process. Di dalam starting condition yaitu tahapan fasilitasi kerjasama di antara stakeholder yang ada. Ada dua issue penting dalam tahapan ini yaitu ketidakseimbangan sumberdaya yang dimiliki oleh masing-masing stakeholders dan insentive supaya berpartisipasi. Apabila sumberdaya dan kekuatan yang dimiliki oleh masing-masing stakeholder tidak seimbang, maka kerjasama akan dimanipulasi oleh stakeholders yang memiliki sumberdaya dan kekuatan banyak. Oleh karenanya jika hal itu terjadi, maka mesti ada komitmen untuk membantu stakeholders yang lemah. Hal lainnya yang tidak kalah penting adalah keharusan adanya insentive supaya stakeholders yang lemah bisa gigih bergabung untuk bekerjasama. Dan terakhir mesti adanya antisipasi terhadap terjadinya konflik di dalam kerjasama sehingga di awal harus dibangun rasa percaya antar satu dengan yang lain.

Model lainnya adalah model yang cukup terkenal yang dipopulerkan John M Bryson dan Barbara C. Crosby (2006) dengan istilah cross-sector collaboration. Dan di dalam buku ini, teori tersebut akan digunakan khusunya di dalam tahapan proses. Dimana collaborative governance terdiri dari initial condition, structure governance, process, contingencies and constraints, outcomes dan accountabilities. Fokus dari buku ini akan mengeksplorasi dari sisi prosesnya yang terdiri dari; (1) forging agreements yang merupakan kesepakatan bersama seluruh stakeholders untuk melakukan kerjasama, (2) building leadership yaitu perlu adanya kepemimpinan baik formal maupun informal sebagai komite atau manajer dari kerjasama tersebut, (3) building legitimacy dimana pentingnya membangun legitimasi dengan adanya struktur, proses, dan strategi yang relevan dengan keadaan di sekitarnya, (4) building trust yaitu membangun kepercayaan antar stakeholders yang bekerjasama dan ini sifatnya sangat penting sekali di dalam collaborative governance, (5) managing conflict yaitu mengelola konflik yang ada mengingat besarnya kepentingan yang muncul dari masingmasing stakeholders yang terlibat di dalam kerjasama, dan (6) planning tahapan yang sangat penting di dalam menentukan visi, misi, tujuan, tahapan, pelaksanaan, keterlibatan dan peran 
dari masing-masing stakeholders, sehingga planning ini sangat menentukan keberhasilan dari kerjasama..

sebagian wilayah Kabupaten Bintan merupakan wilayah Free Trade Zone/kawasan bebas. Free Trade Zone merupakan pengembangan konsep Special Economic Zone (SEZ), dimana SEZ (Kawasan Ekonomi Khusus /KEK) sebagai sebuah terminologi makro untuk kawasan yang ditetapkan untuk menyediakan lingkungan yang secara internasional kompetitif serta bebas dari berbagai hambatan berusaha dalam rangka memacu peningkatan ekspor nasional. Konsep ini dapat ditemukan di negara India dan Filipina. Di India dikenal tiga jenis umum Special Economic Zone (SEZ) meliputi : (a) SEZ for multiproduct, yaitu SEZ yang terdiri dari sejumlah perusahaan yang tergolong dalam lebih dari satu sektor, yang didalamnya juga terdapat kegiatan perdagangan dan pergudangan; (b) SEZ for specific sector, yaitu SEZ bagi satu sektor tertentu saja (bisa lebih dari satu perusahaan) atau SEZ untuk berbagai pelayanan satu sektor, seperti dalam pelabuhan atau bandar udara; dan (c) SEZ for Free Trade and Warehouse yaitu SEZ yang secara khusus menyediakan pelayanan fasilitas kegiatan perdagangan bebas dan pergudangan, fasilitasnya bisa untuk kegiatan yang multi sektor maupun untuk satu sektor tertentu saja. Di Filipina, kawasan-kawasan semacam ini dapat berbentuk Industrial Estates (IES), Export Processing Zones (EPZs), Free Trade Zone, dan Tourist/Recreational Centers (Muzwardi, 2017).

SEZ sebagai sebuah model untuk menyebutkan kawasan dengan kebijakan ekonomi terbuka yang didalamnya mencakup Free Trade Zone (FTZ), Export Processing Zone (EPZ), pelabuhan (Port), High Tech Industrial Estate dan lain sebagainya atau dikenal dengan sebutan zones within zone. Konsepsi ini memberikan otoritas kepada badan pelaksana untuk mengoperasikan SEZ secara penuh atas mandat dari pemerintah pusat.

SEZ merupakan konsep pengembangan kawasan ekonomi ataupun kawasan strategis nasional yang pada umumnya bertujuan untuk meningkatkan (Pusat Kajian Strategis PU, 2012), pembangunan dan perekonomian wilayah agar terjadi pemerataan pembangunan dan kesejahteraan masyarakat di seluruh wilayahIndonesia.”.

Penggunaan konsep Free Trade Zone merupakan pengembangan dari SEZ (Kawasan Ekonomi Khusus /KEK) dipersiapkan untuk memaksimalkan kegiatan industri, ekspor, impor, dan kegiatan ekonomi lain yang memiliki nilai ekonomi tinggi. adalah usaha pengembangan tata kelola pemerintahan dengan memanfaat semua potensi yang ada. Pengembangan Free Trade Zone bertujuan untuk mempercepat perkembangan daerah dan sebagai model terobosan pengembangan kawasan untuk pertumbuhan ekonomi, antara lain industri, pariwisata, dan perdagangan sehingga dapat menciptakan lapangan pekerjaan. Free 
trade zone merupakan konsep yang lahir dari tujuan negara-negara untuk mengejar kesuksesan melalui penggunanan kawasan bebas yang bersifat tetap dan terus menerus.

\section{PEMBAHASAN}

Bintan merupakan pulau terbesar di Provinsi Kepulauan Riau dengan posisi yang strategis dan potensi investasi yang besar terutama di bidang pariwisata dan industry maritime. Kabupaten Bintan memiliki banyak investor asing yang menanamkan investasinya. lebih dari 22 perusahaan yang banyak berkategori besar seperti: Nidec, Perpperel+ Fuch, Yokogawa, dan Yoshikawa yang beroperasi di Bintan Inti Industrial Estate (BIIE). Pusat industry di Bintan berada di Lobam, Bintan bagian utara yang memiliki infrastruktur dan pelayanan berkelas internasional.Selain Bintan Inti Industrial Estate (BIIE) yang menampung sebagian besar perusahaan manufaktur dan garmen, ada juga kawasan industry maritime di Bintan timur yang diperuntukan sebagai industry pembangunan kapal. Total nilai investasi asing di Bintan pada akhir 2012 mencapai US\$ 897.732.068 dengan jumlah 105 proyek. Ditahun 2013 nilai PMA mencapai US\$807.402.000 dengan 112 proyek investasi. Tahun 2015 nilai investasi PMA tidak banyak berubah yaitu di angka US\$ 810.538. Ditahun 2016 investasi asing yang terealisasi sebesar US\$ 789.476.193(Muzwardi, 2017).

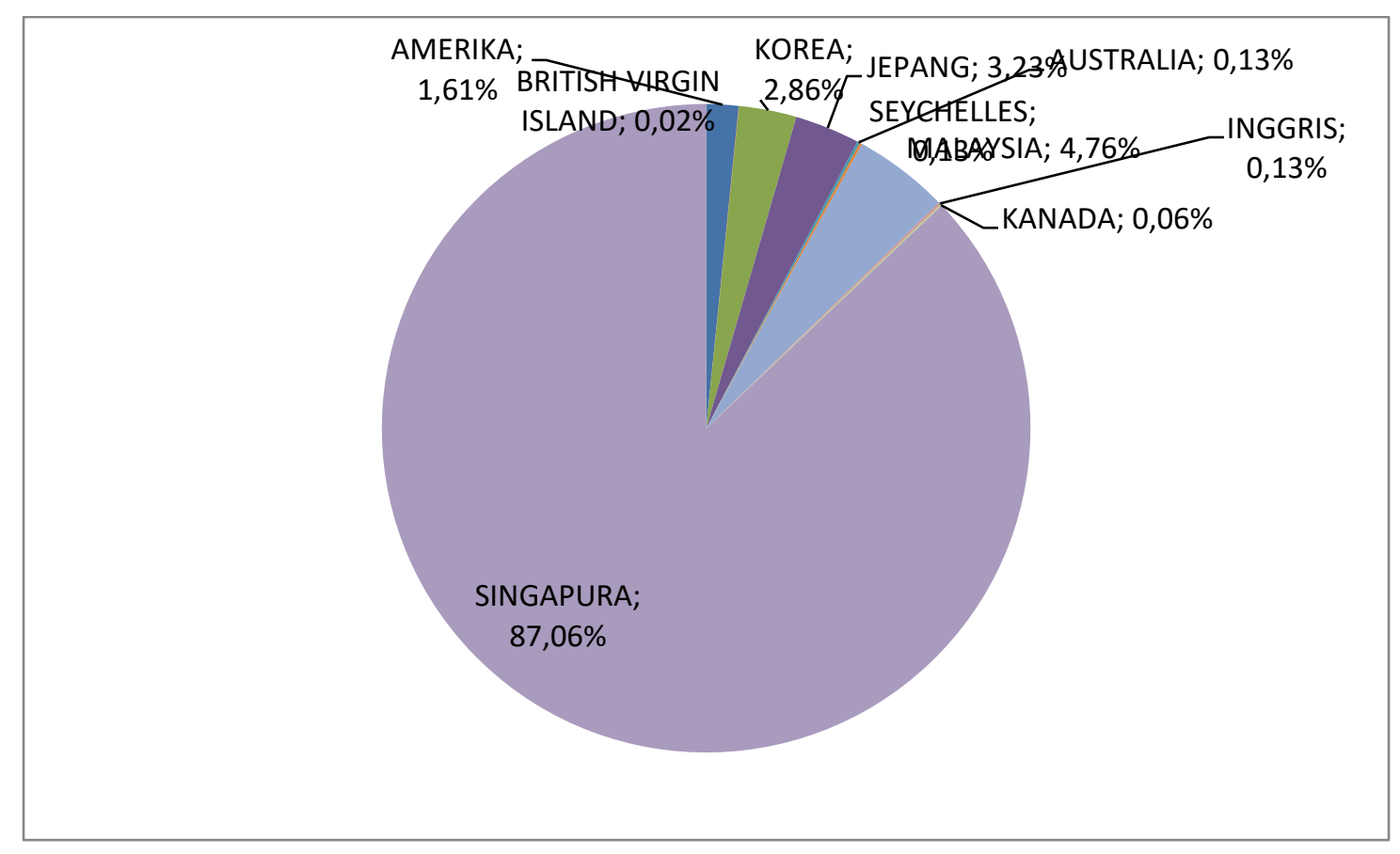

Gambar 1. Grafik Persebaran investasi Asing Pernegara di Bintan tahun 2016 Sumber: BP Bintan 2017 
Bintan adalah wilayah yang pembangunannya diprioritaskan karena mempunyai pengaruh penting dalam lingkup Provinsi Kepulauan Riau terhadap ekonomi, sosial, budaya, dan/atau lingkungan. Beberapa kawasan stratgeis di Bintan menjadi kawasan prioritas pembangunan berdasarkan Perda Kabupaten Bintan No. 2 tahun 2012 pasal 42 wilayah strategis meliputi: kawasan Industri Lobam, kawasan Industri Galang Batang, kawasan Industri Maritim di Kecamatan Bintan Timur, kawasan Pariwisata Lagoi, kawasan Pariwisata Sebong Pereh dan Sebong Lagoi, kawasan Pariwisata sepanjang pantai Trikora dan sepanjang pantai di Kecamatan Gunung Kijang, kawasan Taman Wisata Laut Pulau Tambelan di Kecamatan Tambelan, kawasan Ibukota Kabupaten Bintan Bandar Seri Bentan, kawasan Wisata Terpadu Kuala Sempang, kawasan Wisata Bahari di Mapur, kawasan Perkotaan Kijang dan Tanjung Uban, kawasan Minapolitan Mantang, Bintan Timur dan Bintan Pesisir, kawasan strategis Pusat Kegiatan Lokal Promosi Tambelan.

Pembiayaan pengembangan kawasan strategis dialokasikan dari sumber dana anggaran Pemerintah, Pemerintah Provinsi Kepulauan Riau, dan Pemerintah Kabupaten Bintan serta dari dana investasi perorangan dan masyarakat (swasta/investor) maupun dana yang dibiayai bersama (sharing) baik antar Pemerintah Pusat dan Pemerintah Provinsi Kepulauan Riau, antar Pemerintah dan Pemerintah Kabupaten Bintan maupun antara swasta/investor dengan Pemerintah dan/atau Pemerintah Kabupaten Bintan, dan dana lain-lain. Kawasan Bintan terus berbenah dengan membangun Kawasan Industri Internasional Bintan, meliputi 4000 Ha lahan industri. 
Berdasarkan penetapan Bintan sebagai kawasan Free Trade Zone melalui PP Nomor 47 Tahun 2007 . Secara umum diartikan bahwa pada kawasan ini diberlakukan kemudahan berusaha dan berinvestasi dengan fasilitas pajak yang tidak dipungut baik itu pajak pertambahan nilai (PPN) pajak Bea masuk dan keluar barang (Ekspor dan Impor), Pajak Barang Mewah (PPnBm) dan juga fasilitas kemudahan bekerja bagi warga negara asing dan lain sebagainya (BP.Bintan 2018). Sesuai PP Nomor 47 Tahun 2007 wilayah FTZ bersifat inclave yaitu Sebagian Pulau Bintan bagian Utara dengan luas 58.750,60 ha termasuk pulau Anak Lobam dengan luas 678,20 ha kemudian Kawasan Industri Maritim Bintan Timur dengan luas 812,60 ha dan Kawasan Industri Galang Batang dengan luas 1.775,80 ha.

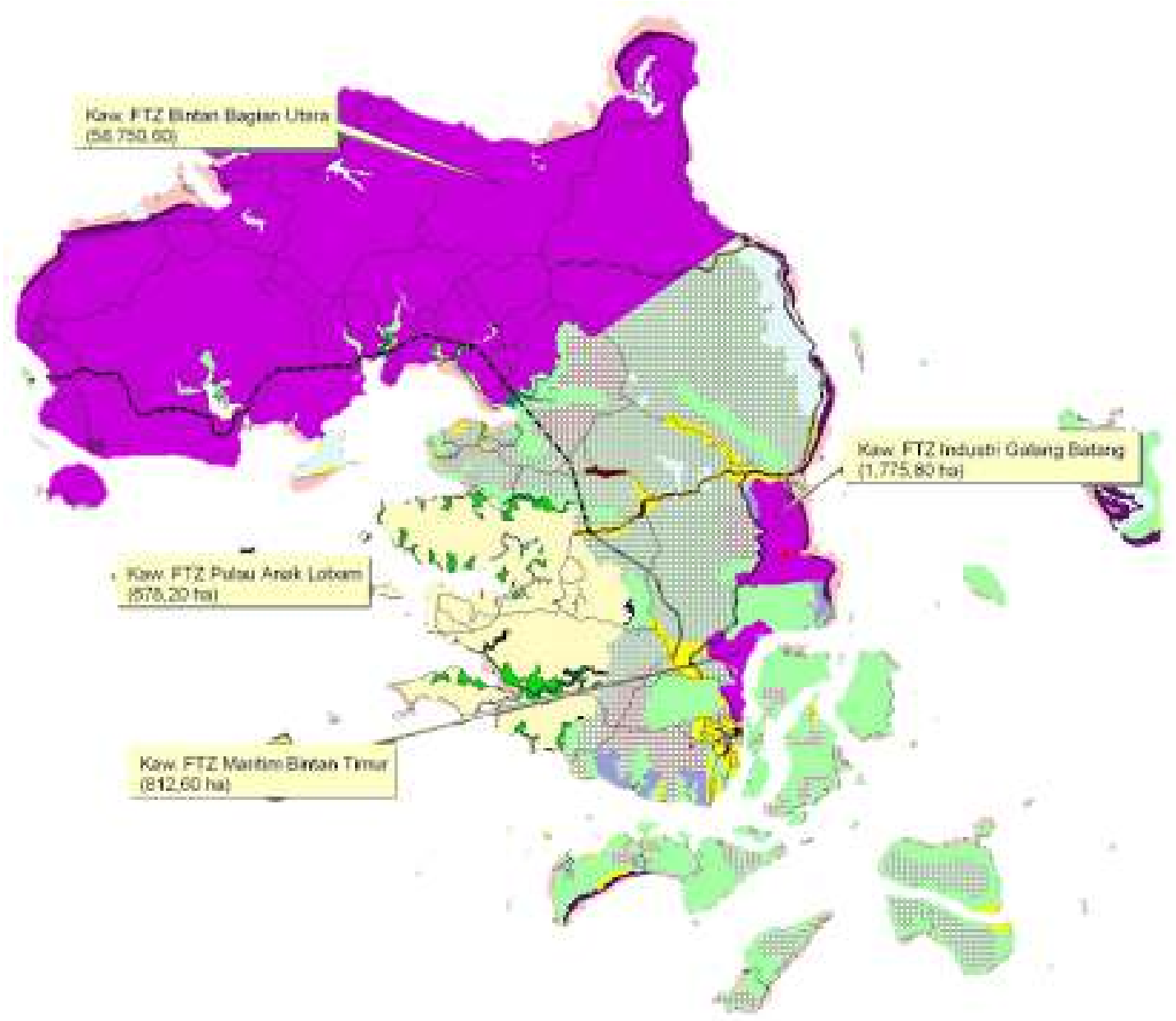

Gambar 2. Peta Kawasan FTZ Bintan

Sumber: BP.Bintan 2017. 
Untuk menarik investasi di kawasan strategis Free Trade Zone Bintan diimplementasikan Collaborative Governance untuk menarik investasi asing. Bentuk Collaborative Governance terbagi menjadi Governance Structure, Service Delivery Characteristics, dan Operational Interactions.

\section{a. Governance Structure}

Dalam pengelolaan Free Trade Zone Bintan pemerintah pusat membentuk Dewan Kawasan Bintan, Bintan Karimun dibawah Dewan Kawasan Nasional melalui Keputusan Presiden Republik Indonesia Nomor 18 tahun 2013 dengan Struktur Organisasi: diKetuai oleh Gubernur Kepulauan Riau dengan Wakil Ketua I Bupati Bintan dan Wakil Ketua II Walikota Tanjung Pinang serta Anggota dari unsur Pimpinan Dirjen Bea dan Cukai Kepri. Dirjen Pajak Kepri, Kanwil Kemenkumham Kepri, Kanwil BPN Kepri, Polda Kepri, Kejati Kepri, Lantamal IV, Guskamlabar: Korem 033/Wirapratama.

Di dalam struktur organisasi ada Walikota Tanjungpinang sebagai anggota, hal inilah yang berbeda dengan Dewan Kawasan Batam dan Dewan Kawasan Karimun. Masuknya Walikota Tanjungpinang di dalam Dewan Kawasan Bintan dikarenakan sebagian wilayah Tanjungpinang Masuk kedalam wilayah Free Trade Zone Bintan. Dalam pengembangan Bintan, Dewan Kawasan Bintan membuat blue print pengembangan dalam Rencana Strategis Kawasan Bintan, melalui pembuatan rencana pengembangan secara efektif dan efisien.

Dalam pembuatan kebijakan umum. Dewan Kawasan Bintan melakukan pembicaraan/konsultasi dengan Badan Pengusahaan Bintan untuk menerima tuntutan stakeholders yakni dengan membuat kebijakan-kebijakan strategis dan mendasar terhadap pembangunan dan pengembangan Bintan. seperti kebijakan tentang perijinan bagi investasi yang ramping. Dewan Kawasan Bintan dibawah Dewan Kawasan Nasional dalam pelaksanaan fungsinya. Kerangka investasi di daerah Free Trade Zone Bintan dibangun oleh Dewan Kawasan Bintan dan Karimun dalam kebijakan investasinya termasuk promosi investasinya. 


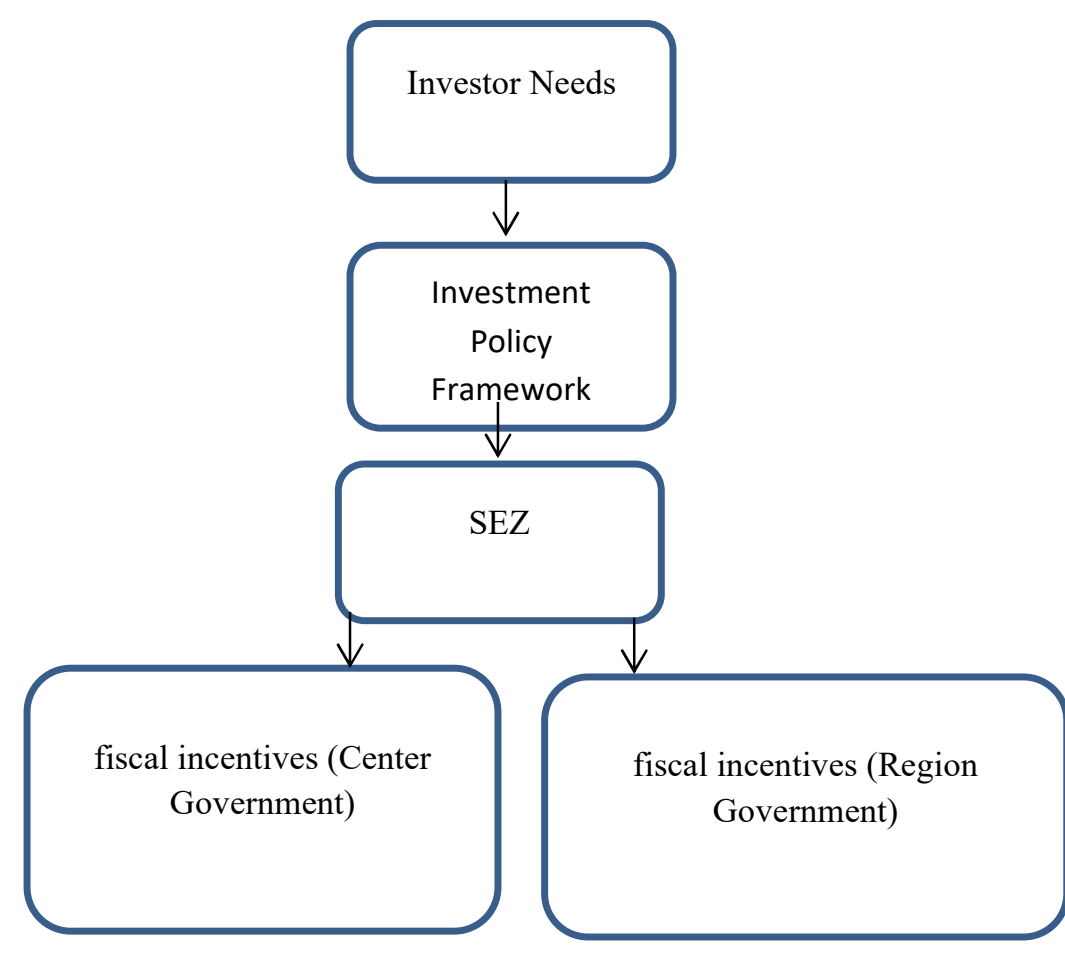

\section{Gambar 3. Investment Policy Framework}

Sumber: diolah dari berbagai data

Untuk melaksanakan kebijakan Dewan Kawasan Bintan maka dibentuklah Badan Pengusahaan Bintan. BP. Bintan merupakan Badan Pengusahaan yang bertugas sebagai Penyelenggaraan pengembangan Kawasan Bintan sebagai kawasan pelabuhan bebas dan perdagangan bebas sesuai kewenangannya. Sasaran kerja BP Bintan adalah membuat landasan hukum bagi pembangunan dan investasi di Kawasan PBPB Bintan membuat arahan kebijakan dan strategi pembangunan Kawasan PBPB Bintan dengan menyusun program dan membuat pedoman dan skala prioritas pembangunan dan investasi di Kawasan Bintan. 


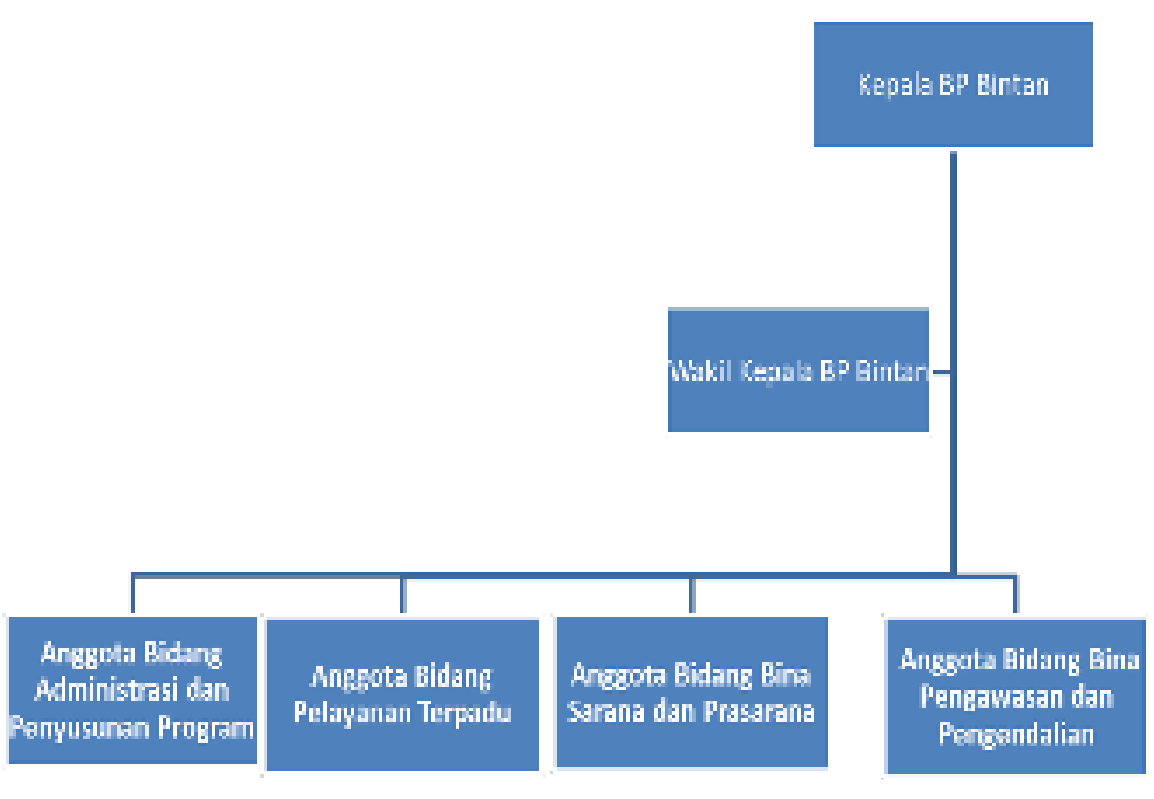

Gambar 4. Struktur Organisasi Badan Pengusahaan Bintan

Sumber: bpbintan.go.id

\section{b. Service Delivery Characteristics}

Pelayanan investasi terhadap investor dilakukan oleh Badan Pengusahaan Bintan. BP Bintan mendapat pelimpahan kewenangan dari Badan Koordinasi Penanaman Modal (BKPM) sehingga BP Bintan mendapat Tupoksi besar dalm bidang perizinan.

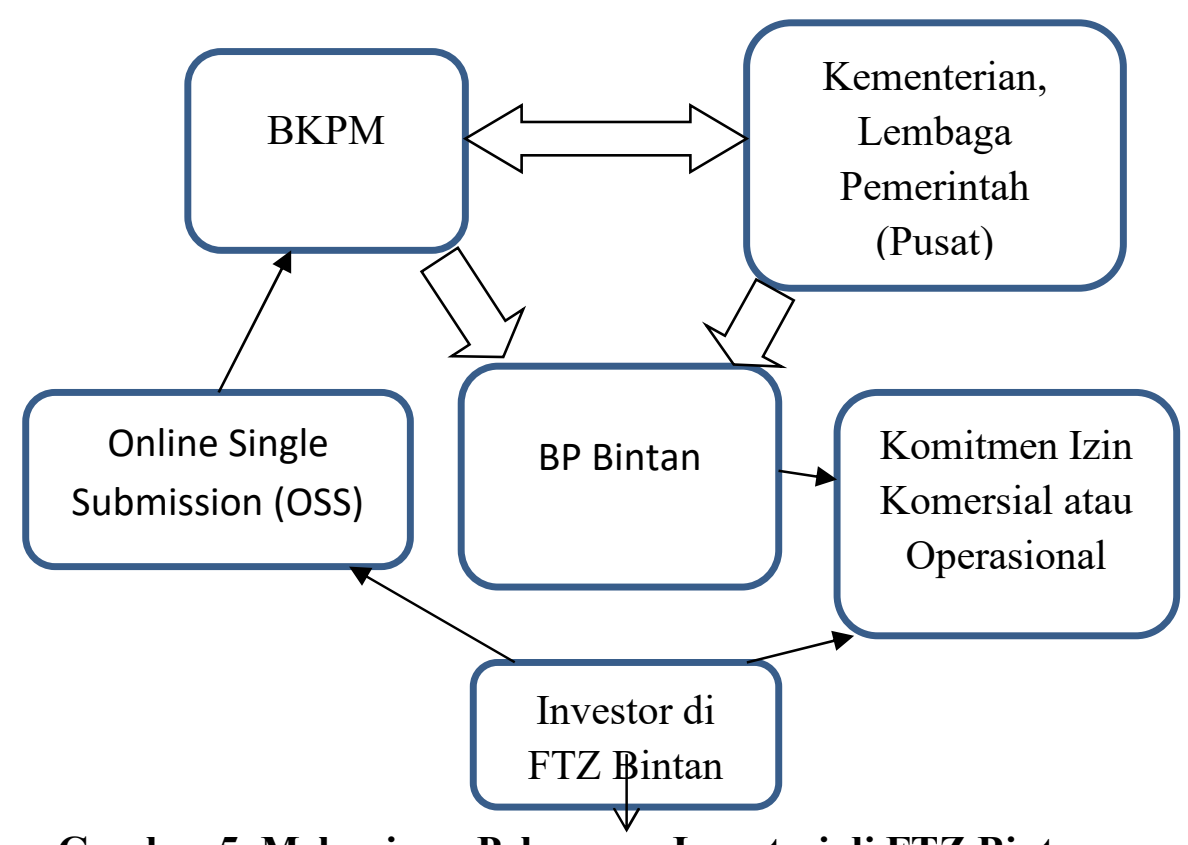

Gambar 5. Mekanisme Pelayanan Investasi di FTZ Bintan

Sumber: diolah dari berbagai data 
Pelayanan investasi dilakukan dengan koordinasi antara Kementrian/LK Pusat dengan BKPM, kewenangan dalam pelayanan investasi selanjutnya dilimpahkan oleh BKPM dan Kementrian/Lembaga pemerintah pusat ke Badan Pengusaha Bintan. Badan Pengusaha Bintan melayani Komitmen Izin Komersial atau Operasional dari Investor di Kawasan FTZ Bintan. Dalam pelaksanaan Online Single Submission (OSS), BP Bintan memfasilitasi investor dalam bentuk pembimbingan dan koordinasi sehingga sinkronisasi bisa terlaksana secara online.

\section{c. Operational Interactions}

Dalam operasional Badan Pengusahaan Bintan melakukan interaksi dengan BP. Batam. Interkasi BP. Bintan dengan BP. Batam terjadi karena BP. Bintan merupakan Satker BP. Batam dan dalam bidang anggaran BP. Batam merupakan Kuasa Pengguna Anggaran dari BP. Bintan, anggaran yang dimaksud meliputi angaran infrastruktur, belanja modal, dan perjalanan dinas. Untuk promosi investasi BP.Bintan menggunakan anggaran APBN. Dalam teknis operasional pelimpahan wewenang perizinan, BP.Bintan berkoordinasi dengan BKPM, dan dalam bidang kebijakan di kawasan FTZ, BP.Bintan berkoordinasi dengan Dewan Kawasan Bintan. Dalam peruntukan dan perluasan lahan/lokasi BP.Bintan berkoordinasi dengan Bappeda Provinsi Kepulauan Riau dan Bappeda Kabupaten Bintan serta Badan Pertanahan Nasional Provinsi.Kepulauan Riau.

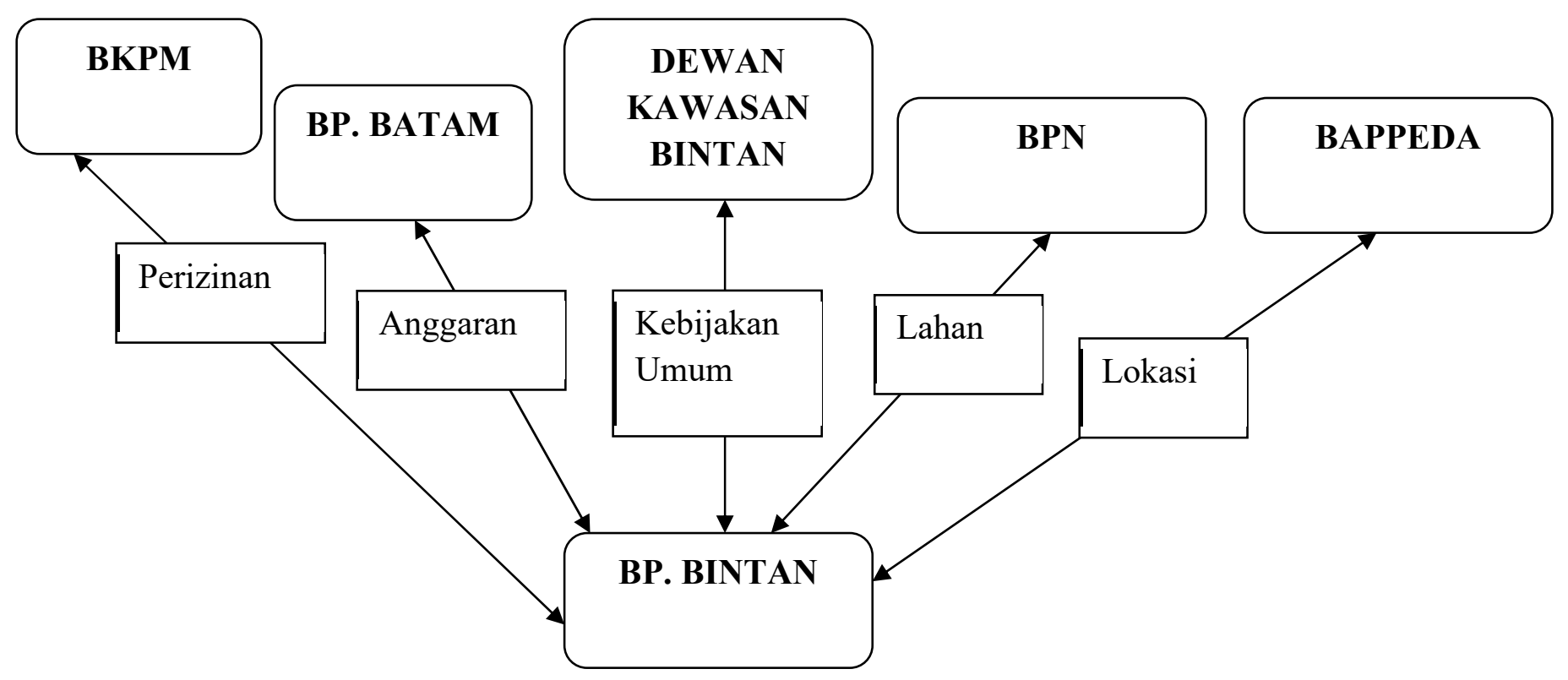

Gambar 6. Interaksi Operasional dalam FTZ Bintan Sumber: Diolah dari berbagai sumber 


\section{KESIMPULAN}

Kesimpulan dalam analisa Collaborative Governance Dalam Pengelolaan Kawasan Free Trade Zone Bintan meliputi :

1. Secara koordinasi hubungan antar organisasi harmonis secara vertikal dan harmonis secara horisontal. Rapat koordinasi dijadwalkan rutin secara lintas instansi dan perencanaan dari pemerintah pusat membuat terkoordinasi secara maksimal. BP.Bintan banyak melibatkan Pemerintah Kabupaten Bintan dan koordinasi dengan pimpinan provinsi.

2. Secara pelayanan investasi, BKPM telah melimpahkan wewenangnya ke BP.Bintan, dan dengan adanya OSS, pelayanan investasi lebih cepat, sehingga BP.Bintan hanya bertugas memberikan izin komitmen kepada investor.

3. Interaksi operasional dalam Kawasan FTZ Bintan terjadi berdasarkan kebutuhan dan tupoksi lembaga-lembaga yang terlibat dalam FTZ Bintan.

\section{DAFTAR PUSTAKA}

\section{Buku}

Bryson, J. M., B. C. Crosby, M. M. Stone and E. Saunoi-Sandgren (2012). Dynamics of cross-sector collaboration: Minnesota's urban partnership agreement from start to finish.

Bryson, J. M., B. C. Crosby and M. M. Stone (2006). “The design and implementation of Cross - Sector collaborations: Propositions from the literature." Public administration review, 66 (s1): 44-55.

Emerson, K. Nabatchi, T. Balogh, S. An Integrative Framework for Collaborative Governance. The Journal of Public Administration Resarch and Theory May 2, 2011.

Mc Guire, M. Collaborative Public Management: Assessing What We Know and How We Know it. Public Aministration Review, Vol. 66, Special Issue: Collaborative Public Management (Dec., 2006). Pp. 33-34

Muzwardi, Ady. (2017) Free Trade Zone menuju Kawasan Ekonomi Khusus Di Batam, Bintan Dan Karimun, Yogyakarta: Expert

O’Flynn, J. \& Wanna, J. 2008. Collaborative Government: Meanings, Dimensions, Drivers, and Outcomes. ANU Press.

Sutarto. Ansell, C. \& Gash, A. Collaborative Governance in Theory and Practice. Journal of Public Administration Research and Theory: J-PART, Vol. 18, No. 4 (Oct., 2008), pp. 543-571 


\section{Jurnal}

Agranoff, Robert. 2012. Collaborating to Manage: A Primer for the Public Sector, Georgetown University Press, USA.

Akmal. 2006. Koordinasi Antar Instansi Terkait Dalam Pelaksanaan Pembangunan di Daerah,Vol,1,DEMOKRASI.

Graddy. 2009. Elizabeth Cross-Sectoral and Performance in Service Delivery, Vo,13, International Review of Public Administration.

Park \& Park. 2009. "Types Of Network Governance And Network Performance: Community Development Project Case",Vol, 13,International Review of Public Administration.

Pusat Kajian Strategis PU. Rencana Strategis Kementerian Pekerjaan Umum 2012

Internet

http://bpbintan.go.id/tentang-bp-bintan (diakses 10 Desember 2018). 